\title{
PENGEMBANGAN MEDIA PEMBELAJARAN BERBASIS ADOBE FLASH DENGAN PENERAPAN TEORI VAN HIELE
}

\author{
Atiaturrahmaniah ${ }^{1}$, Doni Septu Marsa Ibrahim ${ }^{2}$ \\ PGSD Universitas Hamzanwadi \\ email: eyick_nissa@yahoo.co.id ${ }^{1,}$ janganletih@gmail.com ${ }^{2}$
}

\begin{abstract}
Abstrak
Peranan media dalam proses pembelajaran sangat penting, karna media pembelajaran menjadi sarana yang mendekatkan antara konsep abstrak dengan konkrit. Penelitian ini secara umum bertujuan untuk menghasilkan media pembelajaran untuk SD/MI dengan menerapkan teori belajar dari Van Hiele, yang dimana media tersebut dibuat dengan program Adobe Flash. Tujuan khusus yang ingin dicapai adalah menguasai kompetensi matematika yang meliputi pemahaman konsep-konsep matematika terkait geometri, kemampuan memecahkan masalah, dan sikap terhadap pelajaran matematika. Sedangkan manfaat yang diperoleh dari penelitian ini adalah meningkatkan kemampuan peneliti untuk menghasilkan atau menciptakan media pembelajaran yang variatif, sebagai salah satu media yang bisa digunakan guru dalam pembelajaran yang akan diasumsikan dapat meningkatkan kemampuan siswa dalam penguasaan konsep geometri serta membangkitkan minat dan sikap positif siswa terhadap pelajaran matematika.

Untuk mencapai penelitian tersebut, dilakukan penelitian pengembangan media pembelajaran berbasis Adobe Flash dengan penerapan teori Van Hiele. Model pengembangan media pembelajaran ini mengadaptasi dari model pengembangan dari Borg \& Gall. Uji coba dalam penelitian ini menggunakan jenis penelitian quasi eksperimen dengan desain pretest-posttest control design. Tahapan yang dilakukan dalam penelitian ini terdiri dari : (a) tahap desain media pembelajaran; (b) tahap validasi serta revisi; (c) tahap uji coba lapangan menggunakan penelitian quasi eksperimen; (d) Revisi dan pembuatan produk ahir.

Media pembelajaran berbasis flash yang dikembangakan sudah dikatakan efektif digunakan dalam pembelajaran, walaupun terjadi revisi yang cukup banyak dari ahli media terkait kelayakan media untuk diujicobakan dalam proses pembelajaran. Media ini dikatakan efektif, Hal ini sesuai dengan beberapa hasil analisis dari ahli materi, dan hasil observasi bahwa media pembelajaran berbasis flash memiliki kriteria baik.

Keefektifan program media pembelajaran berbasis flash ini juga didukung dengan perbandingan hasil pretest dan posttest yaitu ttabel dicari dengan menggunakan derajat kepercayaan 0.05 dan $\mathrm{db}=41$ sehingga diperoleh $\mathrm{t}$ tabel $=2.680$. Dikarenakan t-hitung $=2.757$, maka t-hitung $>$ t-tabel $2.757>2.680$. Berdasar hasil tersebut maka terdapat perbedaan efektifitas pembelajaran sebelum menggunakan media pembelajaran berbasis adobe flash untuk materi bangun datar dengan setelah menggunakan media pembelajaran berbasis adobe flash untuk materi bangun datar dalam pembelajaran.
\end{abstract}

Kata kunci : Media pembelajaran berbasis Adobe Flash, Teori Van Hiele 


\section{PENDAHULUAN}

Kurikulum yang sesuai dengan jenjang pendidikan dalam kerangka Negara Kesatuan Republik Indonesia salah satunya memperhatikan perkembangan ilmu pengetahuan, teknologi, dan seni. Berdasarkan hal tersebut, sudah seharusnya pendidik menggunakan berbagai sumber belajar melalui teknologi komunikasi, informasi, dan media lain.

Dua unsur dalam suatu proses belajar mengajar yang sangat penting adalah metode mengajar dan media pengajaran. Pembelajaran yang menggunakan media sangat efektif jika dapat dirancang dan digunakan dalam proses pembelajaran yang terarah. Hasil penelitian sebelumnya yang telah dilakukan untuk mengembangkan media website oleh Muhammad Win Afgani (2008), dimana hasil penelitiannya menunjukkan bahwa bahwa penggunaan media website efektif digunakan pada pembelajaran matematika.

Penelitian tentang penerapan teori Van Hiele telah banyak dilakukan, diantaranya penelitian yang dilakukan oleh Nur Yamil (2009) yang merupakan penelitian tindakan kelas (PTK). Hasil penelitiannya menunjukkan bahwa penerapan teori Van Hiele dalam pembelajaran sangat efektif dalam meningkatkan pemahaman siswa terhadap konsepkonsep geometri, yang mulai dari visualisasi sampai tahap abstraksi.

Tujuan dari penelitian ini adalah menghasilkan media pembelajaran berbasis Adobe Flash dengan menerapkan teori belajar dari Van Hiele, yang mampu meningkatkan kompetensi matematika siswa meliputi kemampuan memecahkan masalah, pemahaman konsep-konsep geometri, dan merubah persepsi/anggapan siswa tentang pembelajaran matematika yang akan berdampak pada sikaf positif siswa pada pelajaran matematika.

Penelitian ini diharapkan dapat bermanfaat sebagai sarana untuk menghasilkan atau menciptakan media pembelajaran yang variatif. Dan media yang dihasilkan bisa digunakan guru dalam pembelajaran yang akan diasumsikan dapat meningkatkan kemampuan siswa dalam penguasaan konsep geometri serta membangkitkan minat dan sikap positif siswa terhadap pelajaran matematika.

Menurut Oemar Hamalik (1994:

12) media pengajaran adalah alat, metode, dan teknik yang digunakan 
dalam rangka lebih mengefektifkan komunikasi dan interaksi antara pendidik dan siswa dalam proses pendidikan dan pengajaran di sekolah. Menurut Azhar Arsyad (1997:5) dalam suatu proses belajar mengajar, ada dua unsur yang amat penting yaitu metode mengajar, dan media pengajaran yang keduanya sangat berkaitan. Pemilihan metode mengajar akan mempengaruhi jenis media pengajaran yang akan dipergunakan. Perlu diingat bahwa dalam suatu proses belajar mengajar dimungkinkan menggunakan metode mengajar lebih dari satu sesuai strategi mengajar yang dipilih oleh pendidik.

Adobe Flash merupakan sebuah program yang didesain khusus oleh Adobe dan program aplikasi standar authoring tool professional yang digunakan untuk membuat animasi dan bitmap yang sangat menarik untuk keperluan pembangunan situs web yang interaktif dan dinamis. Adobe Flash didesain dengan kemampuan untuk membuat animasi 2 dimensi yang handal dan ringan sehingga adobe flash banyak digunakan untuk membangun dan memberikan efek animasi pada website, CD Interaktif dan yang lainnya (Wikipedia).
Teori Van Hiele dikembangkan oleh Pierre Van Hiele dan Dina Van Hiele-Geldof sekitar tahun 1950-an. Teori tersebut dikembangkan setelah melihat kesulitan siswa mereka dalam belajar geometri. Model Van Hiele efektif memotivasi siswa dan menciptakan suasana pembelajaran geometeri yang lebih baik. Salleh, M.A. \& Abidin, Z.Z (2013).

Menurut Van Hiele ada 5 tahapan pemahaman geometri, yaitu : "visualization, analysis, informal deducation, formal deducation, and rigor". Model ini menegaskan bahwa siswa bergerak secara berurutan tahap paling awal atau dasar yaitu visualisasi, di mana siswa baru mengenal bangunbangun geometri. Selanjutnya ke tahapan atau urutan yang lebih atas sampai tingkat tertinggi yaitu ketelitian/keakuratan (rigor). Crowley (1987)

\section{METODE PENELITIAN}

Penelitian ini merupakan penelitian pengembangan, yaitu mengembangkan media pembelajaran untuk pelajaran matematika berbasis adobe flash. Fokus penelitian ini adalah mengembangkan media pembelajaran dengan menggunakan program adobe flash serta bagaimana penerapan teori 
Van Hiele dengan media pembelajaran tersebut, dengan bertujuan pada peningkatan kompetensi siswa $\mathrm{SD} / \mathrm{MI}$ dalam pemahaman materi matematika yang berhubungan dengan geomatri, kemampuan memecahkan masalah matematika, dan sikap siswa terhadap matematika.

Pengembangan media pembelajaran berbasis adobe flash dengan penerapan teori Van Hiele ini mengacu pada prosedur pengembangan diadaptasi dari model pengembangan menurut Borg \& Gall. Dalam penelitian ini, peneliti merancang dan memodifikasi model pengembangan tersebut ke dalam 5 tahap yaitu : 1) studi pendahuluan; 2) desain produk; 3) validasi produk; 4) uji coba; dan 5) penyusunan produk akhir.

Tabel 1. Rencana Kegiatan dan Produk yang Dihasilkan

\begin{tabular}{|c|c|c|}
\hline No & Kegiatan & Produk \\
\hline 1 & $\begin{array}{l}\text { Pengembangan draf media pembelajaran berbasis } \\
\text { abode flash (prototife), terdiri dari : } \\
\text { - Analisis kebutuhan } \\
\text { - Penentuan materi dan kompetensi } \\
\text { - Studi pustaka }\end{array}$ & $\begin{array}{l}\text { Draf produk awal } \\
\text { (prototife 1) }\end{array}$ \\
\hline 2 & $\begin{array}{l}\text { Pembuatan media pembelajaran berbasis adobe } \\
\text { flash } \\
\text { - Analisis materi-materi esensial yang } \\
\text { berhubungan dengan teori Van Hiele. } \\
\text { - Mendesain media dengan menggunakan } \\
\text { program adobe flash }\end{array}$ & $\begin{array}{l}\text { Produk berupa } \\
\text { media } \\
\text { pembelajaran } \\
\text { yang sudah final } \\
\text { untuk produk } \\
\text { awal }\end{array}$ \\
\hline 3 & $\begin{array}{l}\text { Uji coba media pembelajaran dengan } \\
\text { kegiatan sebagai berikut; } \\
\text { - Uji ahli (ahli teknologi pembelajaran). } \\
\text { - } \text { Revisi media pembelajaran } \\
\text { - Melakukan uji lapangan dengan melakukan uji } \\
\quad \text { eksperimental }\end{array}$ & $\begin{array}{l}\text { Produk (media } \\
\text { pembelajaran) } \\
\text { yang telah teruji } \\
\text { validitasnya dan } \\
\text { keefektifannya } \\
\text { dengan uji coba, } \\
\text { yang meliputi : } \\
\text { uji coba terbatas } \\
\text { dan uji } \\
\text { eksperimental }\end{array}$ \\
\hline
\end{tabular}

\section{Populasi dan Sampel Penelitian}

Populasi dalam penelitian ini adalah seluruh siswa kelas IV sekolah dasar yang berasal dari SDN 2 Pancor. Dan dalam penelitian ini digunakan studi sampel berjumlah 2 kelas yang berjumlah 42orang, yaitu kelas eksperimen dan kelompok control. 


\section{Instrumen Penelitian}

Instrumen yang digunakan dalam penelitian ini, terdiri dari :

1) Lembar validasi produk. . Instrumen ini digunakan untuk memperoleh data tentang penilaian dari ahli terhadap produk yang dikembangkan. Hasil penilaian ini dijadikan dasar untuk perbaikan sebelum diujicobakan.

2) Pedoman observasi. Pedoman observasi digunakan untuk menjaring data tentang kegiatan pembelajaran yang dilakukan oleh guru di dalam kelas tanpa dan dengan menggunakan media pembelajaran berbasis adobe flash.

3) Tes. Untuk mengumpulkan data tentang kemampuan siswa khususnya pada materi geometri digunakan tes tulis dengan bentuk uraian. Tes dilakukan pada saat uji eksperimetal dan diberikan sebelum dan sesudah pembelajaran.

\section{Analisis Data}

Data yang diperoleh berupa hasil validasi media pembelajaran dianalisis secara deskriptif. Tingkat kelayakan dan kriteria revisi produk mengacu pada pedoman pada tabel berikut.

Tabel 2. Rentang skor dan kriteria revisi

\begin{tabular}{cc}
\hline Interval & Kriteria \\
$>4,0$ & Sangat baik, tidak revisi \\
$3,0-4,0$ & Baik, tidak revisi \\
$2,0-2,9$ & Kurang, revisi \\
$<2,0$ & Sangat kurang, revisi \\
\hline
\end{tabular}

Data yang diperoleh dari hasil criteria yang diajukan oleh Azwar observasi, dilakukan analisis dengan (2007) pada tabel berikut : statistik deskriptif, dengan mengacu

Tabel 3. Skor acuan hasil observasi pembelajaran

\begin{tabular}{|c|c|c|}
\hline Nilai & Intrerval skor & Kriteria \\
\hline A & $\begin{array}{l}\frac{r \text { ac }}{\text { masm oos }} \\
M-1,51 \text { skor } \\
M-<x\end{array}$ & Sangat baik \\
\hline B & $\approx=-0,5^{x}=1,5_{z}$ & Baik \\
\hline $\mathrm{C}$ & $\cong 0,5 \approx$ & Cukup \\
\hline $\mathrm{D}$ & 㥕-1,5 & Kurang \\
\hline $\mathrm{E}$ & 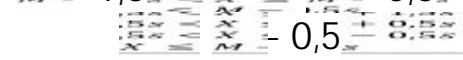 & Sangat kurang \\
\hline
\end{tabular}


Salah satu syarat analisis yang digunakan akan dibahas pada bagian ini adalah uji normalitas data dengan tujuan untuk mengetahui apakah data yang akan diolah tersebut sudah berdistribusi normal atau tidak. Adapun rumus yang akan digunakan untuk menguji normalitas data tersebut adalah dengan menggunakan rumus Liliford. Dengan kriteria keputusan jika $\chi^{2}$ hitung $<\chi^{2}$ tabel dengan interval kepercayaan $95 \%$ maka data tersebut dikatakan berdistribusi normal. Sebaliknya jika $\chi^{2}$ hitung $>$ $\chi^{2}$ tabel dengan interval kepercayaan $95 \%$ maka data tersebut tidak berdistribusi normal. Dan uji homogenitas menggunakan uji $\mathrm{F}$ dengan criteria keputusan jika F-Hitung $\leq \mathrm{F}_{\text {tabel }}$ maka diambil kesimpulan bahwa data tersebut homogen.

Teknik analisis data yang peneliti gunakan dalam penelitian ini adalah dianalisis menggunakan uji statistik t-test berkorelasi dengan rumus.Sugiyono (2) 09

$$
\mathrm{t}=\frac{\overline{\mathrm{X}_{1}}-\overline{\mathrm{X}_{2}}}{\sqrt{\frac{\mathrm{s}_{1}^{2}}{\mathrm{n}_{1}}+\frac{\mathrm{s}_{2}^{2}}{\mathrm{n}_{2}}-2 \mathrm{r}\left(\frac{\mathrm{s}_{1}}{\sqrt{\mathrm{n}_{1}}}\right)\left(\frac{\mathrm{s}_{2}}{\sqrt{\mathrm{n}_{2}}}\right)}}
$$

Ereterangan :

$\left[\bar{H}_{1}=\right.$ rata-rata kelas kontrol

$\mathrm{F}_{2}=$ rata-rata kelas eksperimen $\mathrm{s}_{1}^{2}=$ varians kelas kontrol

$s_{2}^{2}=$ varians kelas eksperimen

$\mathrm{s}_{1}=$ simpangan baku kelas kontrol

$\mathrm{s}_{2}=$ simpangan baku kelas $\mathrm{e}$ ksperimen

$\mathrm{r} \quad=$ korelasi antara dua kelompok

\section{HASIL PENELITIAN}

Tahapan-tahapan yang dilakukan pada penelitian ini adalah sebagai berikut

1. Studi Pendahuluan

Pada studi pendahuluan ini data yang diperoleh berupa data observasi awal. Kegiatan yang dilakukan pada tahapan ini adalah peneliti melakukan beberapa analisis terkait pustaka tentang adobe flash dan teori Van Hiele, kebutuhan pengguna, materi, dan analisis media pembelajaran berbasis flash.

\section{a. Analisis Pustaka}

Pada tahap analisis pustaka ini, peneliti mengumpulkan refrensirefrensi baik dari buku cetak, tutorial, artikel dan jurnal dari internet yang terkait dengan materi adobe flash dan teori Van Hiele. Dimana refrensi-refsenri tersebut akan membantu/sebagai rujukan bagi peneliti untuk membuat media pembelajaran. 
b. Kebutuhan Pengguna

Peneliti mengembangakan media pembelajaran berbasis adobe flash pada mata pelajaran matematika untuk dapat digunakan oleh guru dalam menyampaikan materi di kelas. Peneliti melakukan pengembangan media pembelajaran berbasis adobe flash untuk siswa sekolah dasar dengan penyajian materi secara singkat, mudah dipahami, dan jelas.

c. Analisis Materi

Materi tentang bangun ruang di sekoah dasar untuk kurikulum tingkat satuan pendidikan (KTSP) sudah diajarkan dari sejak I SD sampai kelas VI SD. Buku pelajaran yang digunakan adalah buku terbitan dari BSE. Media pembelajaran berbasis adobe flash yang dibuat ini berdasarkan materi-materi yang ada disekolah dasar, dan mengacu pada tahapan pemahaman geometri dari teori belajar Van Hiele. Dimana, menurut peneliti bahwa tahapan pemahaman geometri di sekolah dasar sampai tahapan ketiga, yaitu tahap pengenalan, tahap analisis, dan tahap pengurutan. Sehingga peneliti membuat media pembelajaran dengan adobe flash berdasarkan tuga tahapan tersebut dan materinya sesuai dengan materi sekolah dasar dari kelas I sampai kelas IV.

\section{Desain Produk}

Produk yang dihasilkan berupa produk awal yang selanjutkan akan mengalami penyempurnaan berdasarkan hasil vaidasi dan uji coba. Dalam membuat media ini peneliti menggunakan Adobe Flash Professional CS3. Pada pase desain atau pembuatan media ini, peneliti melakukan beberapa tahapan, yaitu:

a. Persiapan (pra produksi)

Tahap ini adalah mempersiapkan bahan-bahan yang digunakan untuk membuat media pembelajaran. Adapun bahan-bahan yang disiapkan antara lain kamputer/laptop yang sudah terinstal software adobe flash CS3, membuat story board, menyiapkan rekaman suara yang akan digunakan.

b. Tahap Pembuatan (produksi) 
Pada tahapan ini, peneliti mulai membuat media sesuai dengan story board yang sudah disusun sebelumnya. Ini adalah produk awal yang akan validasi oleh ahli sebelum diujicobakan/digunakan dalam pembelajaran.

c. Penyusunan Instrumen Penelitian

Setelah tahapan desain produk selesai, selanjutnya dilakukan penyusunan instrumen yang akan digunakan dalam penelitian, meliputi: instrumen lembar validasi untuk ahli materi dan ahli media, dan instrumen untuk observasi pembelajaran dengan dan tanpa menggunakan media pembelajaran berbasis adobe flash.

3. Tahap Validasi Produk

Tahap validasi dilakukan oleh beberapa ahli sebelum peneliti menerapkan langsung pada proses pembelajaran di kelas. Validasi program dilakukan oleh ahli materi dan ahli media. Adapun hasil validasi oleh masing-masing ahli sebagai berikut.

a. Ahli Media

Tabel 4. Hasil Validasi Ahli Media

\begin{tabular}{|c|c|c|c|c|c|}
\hline No & Aspek & $\begin{array}{l}\text { Skor } \\
\text { Max }\end{array}$ & Skor & $\begin{array}{c}\text { Rata- } \\
\text { rata }\end{array}$ & Kriteria \\
\hline 1 & $\begin{array}{l}\text { Struktur dan efesiensi } \\
\text { media }\end{array}$ & 12 & 9 & 3.00 & Baik, tidak revisi \\
\hline 2 & Bahasa dan tampilan & 32 & 21 & 2.62 & Kurang, revisi \\
\hline 3 & Efektifitas & 16 & 9 & 2.25 & Kurang, revisi \\
\hline 4 & $\begin{array}{l}\text { Integrasi teori Van } \\
\text { Hiele }\end{array}$ & 12 & 9 & 3.00 & Baik, tidak revisi \\
\hline & Jumlah & & & 2.72 & Revisi \\
\hline
\end{tabular}

Berdasarkan hasil dari validasi ahli media terlihat bahwa dari aspek: bahasa dan tampilan serta aspek efektifitas, kriteria media masih termasuk pada kategori kurang dan perlu dilakukan penyempurnaan (revisi). Sedangkan skor rata-rata yang diperoleh secara keseluruhan untuk media adalah 2.72, terletak pada interval 2.0 - 2.9 dengan kriteria "kurang, revisi" sehingga media yang telah dibuat harus dilakukan revisi lagi sebelum diujicobakan ke sekolah.

b. Ahli Materi 
Tabel 5. Hasil Validasi Ahli Materi

\begin{tabular}{llcccl}
\hline No & \multicolumn{1}{c}{ Aspek } & $\begin{array}{c}\text { Skor } \\
\text { Max }\end{array}$ & Skor & $\begin{array}{c}\text { Rata- } \\
\text { rata }\end{array}$ & \multicolumn{1}{c}{ Kriteria } \\
\hline 1 & Ahli materi 1 (Dosen) & 40 & 20 & 3.00 & Baik, tidak revisi \\
2 & Ahli materi 2 (Guru) & 40 & 32 & 3.20 & $\begin{array}{l}\text { Baik, tidak revisi } \\
\text { Tidak ada } \\
\text { Jumlah }\end{array}$ \\
& & & $\mathbf{3 . 1 0}$ & adaisi \\
\hline
\end{tabular}

Hasil yang diperoleh dari ahli materi yaitu 3.00 (ahli materi 1) dan 3.20 (ahli materi 2) berada pada kriteria baik dan tidak perlu direvisi. Adapun hasil dari validasi ahli materi secara keseluruhan diperoleh skor ratarata 3.10 , berada pada interval 3.0 - 4.0 dengan kriteria "baik, tidak revisi".

4. Tahap Uji Coba

\section{a. Proses Penerapan}

Uji coba media pembelajaran ini dilakukan dengan tujuan untuk mengetahui kekurangan dan kelemahan dari program yang telah jadi, untuk melihat keefektifan program tersebut bila digunakan dalam pembelajaran. Uji coba media pembelajaran berbasis flash dilakukan pada kelas IV sekolah dasar. Ujicoba dilakukan hanya melibatkan satu sekolah dasar saja, yaitu SDN 2 pancor, dimana sekolah tersebut masih menggunakan KTSP.

b. Uji Normalitas Data

1. Hasil pretest

Data dari hasil pretest harus di uji normalitas dahulu untuk mengetahui kelas yang berdistribusi normal yaitu dengan menggunakan uji Lilliefort. Uji normalitas dengan menggunakan uji Lilliefors ini dilakukan untuk mengetahui kenormalan suatu data yang berupa data tunggal. Hasil uji normalitas kelas IVA dan kelas IVB dapat dilihat pada tabel berikut.

Tabel 6. Uji normalitas data pretest

\begin{tabular}{lllll}
\hline Kelas & L-hitung & Dk & L-tabel & Keterangan \\
\hline IVA & 0.16 & 0.05 & 0.190 & Normal \\
IVB & 0.13 & 0.05 & 0.182 & Normal \\
\hline
\end{tabular}


Berdasarkan tabel di atas untuk kelas IVA diperoleh hasil L-hitung $=0.16$ dan Ltabel $=0.190$, jadi Lhitung $<$ Ltabel . Sehingga Ho diterima dan dapat diambil kesimpulan bahwa data tersebut normal. Sedangkan kelas IVB diperoleh $\mathrm{L}$ hitung $=0.13$ dan $\mathrm{L}$ tabel $=0.182$, jadi Lhitung $<$ Ltabel . Sehingga Ho diterima dan dapat diambil kesimpulan bahwa data tersebut normal.

2. Hasil Posttest

Uji normalitas data posttest dengan menggunakan rumus Lilliefors dapat dilihat dalam tabel berikut.

Tabel 7. Uji normalitas data postest

\begin{tabular}{lllll}
\hline Kelas & L-hitung & Dk & L-tabel & Keterangan \\
\hline IVA & 0.13 & 0.05 & 0.190 & Normal \\
IVB & 0.10 & 0.05 & 0.182 & Normal \\
\hline
\end{tabular}

Berdasarkan tabel di atas untuk kelas IVA diperoleh hasil L-hitung $=0.13$ dan Ltabel $=0.190$, jadi Lhitung $<$ Ltabel . Sehingga Ho diterima dan dapat diambil kesimpulan bahwa data tersebut normal. Sedangkan kelas IVB diperoleh $\mathrm{L}_{\text {hitung }}=0.10$ dan $\mathrm{L}$ tabel $=0.82$, jadi Lhitung $<$ Ltabel - Sehingga Ho diterima dan dapat dikatakan bahwa kelas eksperimen dan kontrol berdistribusi normal. c. Uji Homogenitas Data

1. Hasil Pretest

Uji homogenitas atau uji kesamaan dua varians merupakan uji untuk mengetahui apakah kedua sampel yang akan menjadi sampel penelitian yaitu menjadi kelas ekperimen dan kelas kontrol memiliki varians yang sama (homogen) atau berbeda antara kelas IVA dengan IVB. Hasil perhitungan uji $F$ dapat dilihat dalam tabel berikut.

Tabel 8. Uji homogenitas data pretest

\begin{tabular}{lllll}
\hline Kelas & Dk & F-hitung & F-tabel & $\begin{array}{l}\text { Keterangan } \\
\text { homogen }\end{array}$ \\
\hline
\end{tabular}


Dari tabel di atas uji kesamaan dua varians kemampuan awal (pretest) diperoleh Fhitung $<$ Ftabel. Dari hasil analisis baik uji normalitas dan uji homogenitas kedua kelas yaitu VII A dan VII B, kedua-duanya memenuhi prasyarat sebagai kelas eksperimen dan kelas kontrol.

2. Hasil Post test

Setelah peserta didik diberikan perlakuan dengan metode pembelajarandengan menggunakan media pembelajaran berbasis flash untuk kelas eksperimen dan metode pembelajaran konvensional untuk kelas kontrol maka dilakukan post test untuk mengetahui kemampuan peserta didik setelah dilakukan pembelajaran dengan dua metode tersebut. Data dari hasil posttest juga harus dianalisis dengan uji homogenitas atau uji varians sebagai prasyarat untuk melakukan selanjutnya yaitu uji-t. Hasil perhitungan data untuk uji homogenitas diperoleh,

Tabel 9. Uji homogenitas data postest

\begin{tabular}{lllll}
\hline Kelas & Dk & F-hitung & F-tabel & Keterangan \\
IVA dan IVB & 0.05 & 1.289 & 2.15 & homogen \\
\hline
\end{tabular}

Dari tabel tersebut dapat kelas control dianalisis dengan uji t. dilihat bahwa nilai Fhitung < Berdasarkan hasil perhitungan Ftabel, yaitu $1.289<2.15$. diperoleh bahwa thitung $=2.76$ dan tabel Sehingga dapat disimpulkan bahwa kelas eksperimen dan kontrol homogen, yang $=2,68$ dengan menggunakan derajat kepercayaan 0,05 dan $\mathrm{db}=41$ sehingga diperoleh. Dikarenakan thitung berarti kedua kelas tersebut mempunyai karakteristik yang sama.

\section{Pengujian Hipotesis}

Hasil tes akhir (posttest) yang diperoleh pada kelas eksperimen dan $=2.76$, maka thitung $>$ tabel yaitu $2.757>$ 2.680. Sehingga $\mathrm{H}_{o}$ ditolak dan $\mathrm{H}_{\mathrm{a}}$ diterima. Dan dapat diambil kesimpulan bahwa nilai rata-rata kelas eksperimen lebih baik dari nilai ratarata kelas kontrol. 


\section{PEMBAHASAN}

Media pembelajaran yang telah dibuat, dari hasil penilaian oleh ahli materi skor rata-rata yang diperoleh secara keseluruhan untuk media adalah 2.72 , terletak pada interval 2.0 - 2.9 dengan kriteria "kurang, revisi. Hal ini menunjukkan bahwa media yang telah dibuat masih belum bisa digunakan pada proses pembelajaran sebelum dilakukan revisi atau penyempurnaan terutama pada aspek bahasa , tampilan, dan efektifitas media. Sedangkan hasil yang diperoleh dari ahli materi secara keseluruhan diperoleh skor rata-rata 3.10 , berada pada interval $3.0-4.0$ dengan kriteria "baik, tidak revisi".

Berdasarkan analisis data hasil belajar siswa, penerapan pembelajaran dengan menggunakan media berbasis flash dapat meningkatan hasil belajar siswa. Hal ini dapat dilihat perbedaan rata-rata hasil skor posttest pada kelas eksperimen dibandingkan dengan kelas kontrol. Rata-rata kelas eksperimen adalah 79.09 dan ata-rata kelas control adalah 78.75. Dari hasil analisis diperoleh bahwa thitung sebesar 2,76 dan tabel sebesar 2,680. Dari uji t tersebut, diketahui bahwa thitung $>$ tabel, maka Ho ditolak sehingga dapat disimpulkan bahwa rata-rata hasil belajar kelas eksperimen lebih tinggi dari rata-rata hasil belajar kelas kontrol.

Berdasarkan hasil yang diperoleh menunjukkan bahwa hasil belajar siswa yang mendapat pembelajaran dengan bantuan media berbasis adobe flash lebih baik dari pada siswa yang mendapatkan pembelajaran tanpa bantuan media pembelajaran atau mendapat pembelajaran konvensional.

\section{DAFTAR PUSTAKA}

Abu, Mohd Salleh \& Abidin, Zaid Zainal. (2013). Improving the Levels of Geometri Thinking of Secondary School Student Using Geometry LearningVideo Based on Van Hiele Theory. International Journal of Evaluation and Research in Education (IJERE) Vol. 2 March 2013.

Anik Ghufron., Sri Sumardiningsih., \& Widyastuti Purbani. (2007). Panduan penelitian dan pengembangan. Yogyakarta : Universitas Negeri Yogakarta.

Azhar Arsyad. (2006). Media pembelajaran.Jakarta: PT Radja Grafindo Perkasa.

Borg, W.R., \& Gall, M.D. (1983). Educational research an introduction. New York : Logman. 
Crowley, Mary L. (1987). The Van Hiele Model of Development of Geometric Thought. NCTM

Hamalik.O. (1991).Manajemen belajar di perguruan tinggi bandung. Bandung: Sinar Baru.

M. Nur Yadil. (2009). Penerapan Model Pembelajaran Van Hiele Untuk Meningkatkan Pemahaman Siswa SMP Karunadipa Palu terhadap Konsep Bangun-Bangun Segiempat. Prosiding: Seminar Nasional Matematika dan Pendidikan Matematika.

Nurul Zuriah. (2006). Metodologi Penelitian Sosial dan Pendidikan. Jakarta : PT. Bumi Akasara.

Saifuddin Azwar. (2007). Tes prestasi (fungsi pengembangan pengukuran prestasi belajar). Yogyakarta: Pustaka Pelajar.

Subana; Moersetyo Rahadi; Sudrajat. (2005). Statistik Pendidikan. Bandung: Pustaka Setia.

Sugiyono. (2009). Metode Penelitian Kuantitatif Kualitatif dan $R$ \& $D$. Bandung: Alfabeta.

Wikipedia. (2015). Adobe Flash. Diambil tanggal 20 April 2015 dari situs: http://id.wikipedia.org/wiki/Ado be_Flash 